\title{
NEGLECTED TROPICAL DISEASES IN BRAZIL
}

\author{
José Angelo L. LINDOSO(1,2,3) \& Ana Angélica B.P. LINDOSO(1,4,5)
}

\begin{abstract}
SUMMARY
Poverty is intrinsically related to the incidence of Neglected Tropical Diseases (NTDs). The main countries that have the lowest human development indices (HDI) and the highest burdens of NTDs are located in tropical and subtropical regions of the world. Among these countries is Brazil, which is ranked $70^{\text {th }}$ in HDI. Nine out of the ten NTDs established by the World Health Organization (WHO) are present in Brazil. Leishmaniasis, tuberculosis, dengue fever and leprosy are present over almost the entire Brazilian territory. More than $90 \%$ of malaria cases occur in the Northern region of the country, and lymphatic filariasis and onchocerciasis occur in outbreaks in a particular region. The North and Northeast regions of Brazil have the lowest HDIs and the highest rates of NTDs. These diseases are considered neglected because there is not important investment in projects for the development of new drugs and vaccines and existing programs to control these diseases are not sufficient. Another problem related to NTDs is co-infection with HIV, which favors the occurrence of severe clinical manifestations and therapeutic failure. In this article, we describe the status of the main NTDs currently occurring in Brazil and relate them to the HDI and poverty.
\end{abstract}

KEYWORDS: Tropical diseases; Poverty; Vulnerability; Brazil.

\section{INTRODUCTION}

Neglected tropical diseases (NTDs) have a higher prevalence in regions between latitudes $35^{\circ} \mathrm{N}$ and $35^{\circ} \mathrm{S}$, with altitudes below 2,200 meters and temperatures ranging from $15^{\circ} \mathrm{C}$ to $40^{\circ} \mathrm{C}$. The populations living in these regions earn about US\$ 1.00 a day and are considered the poorest people in the world. About 1.2 billion people worldwide who live in absolute poverty, mainly in three developing regions (sub-Saharan Africa, Asia, and Latin America), are vulnerable to NTDs ${ }^{20,21}$. In these regions, poverty is closely associated with the prevalence of NTDs and with increased vulnerability to such diseases. Infection by the causative agents of NTDs causes disability and disfigurement, with profound economic, social, and political impact. The direct effects of NTDs can be observed in health, education, agriculture, and the economy. NTDs may be caused by parasitic (helminthic and protozoan), bacterial, fungal, ectoparasitic, or viral agents. A group of 13 diseases is responsible for about 57 million disability-adjusted life years lost per year ${ }^{18,20}$. More than $90 \%$ of the burden results from seven major diseases that are highly prevalent and difficult to control $^{20}$. The classification of these diseases into three categories was based on emergence, control, and drug availability (World Health Organization, WHO). Category one includes the major NTDs (dengue fever, human African trypanosomiasis, and leishmaniasis), which are not under control and are emerging. Category two includes diseases (malaria, schistosomiasis, and tuberculosis) for which a control strategy is available, although the disease burden remains. Category three includes diseases (leprosy, Chagas' disease, lymphatic filariasis, and onchocerciasis) for which the control strategy proved to be effective; the burden of these diseases is falling, and there is a plan for their elimination (Table 1). However, other diseases that are caused by helminthic and bacterial agents cause disability and handicap and are considered the highest-burden NTDs. NTDs have a global prevalence of about 2.60 billion $^{20}$. Hookworm infection is the most prevalent disease, and the number of deaths caused by leishmaniasis, schistosomiasis, and human African trypanosomiasis is very high.

This review focuses on the main NTDs occurring in Brazil and describes their status and problems related to their control, drug development, and association with poverty.

\section{BURDEN OF NEGLECTED TROPICAL DISEASES IN BRAZIL}

According to the WHO, several of the world's major NTDs occur in Brazil. However, the burden of these diseases differs by region. The number of people affected by NTDs is more elevated in areas with greater poverty. There is a direct relationship between the prevalence of these diseases and the human development index (HDI). There is a high prevalence of NTDs in Brazil and most of them occur in poor regions, mainly in the north and northwest of the country (Fig. 2). Malaria, Chagas' disease, leishmaniasis, schistosomiasis, dengue fever, leprosy, onchocerciasis, and lymphatic filariasis are the NTDs with the highest prevalence rates ${ }^{14,16}$. Tuberculosis, which is not considered a tropical disease, is also highly prevalent in Brazil (Table 2).

Work published as part of the celebration of the $50^{\text {th }}$ anniversary of the São Paulo Institute of Tropical Medicine (1959/2009).

(1) Instituto de Infectologia Emílio Ribas-SES-SP, São Paulo, SP, Brasil.

(2) Laboratório de Soroepidemiologia (LIM-38 HC-FMUSP), São Paulo, SP, Brasil

(3) Laboratório de Soroepidemiologia e Imunobiologia do Instituto de Medicina Tropical de São Paulo-USP, São Paulo, SP, Brasil.

(4) Faculdade de Medicina-Sorocaba-Pontifícia Universidade Católica de São Paulo, Sorocaba, SP, Brasl.

(5) Serviço de Vigilância Epidemiológica Alexandre Vranjac-SES-SP, São Paulo, SP, Brasil.

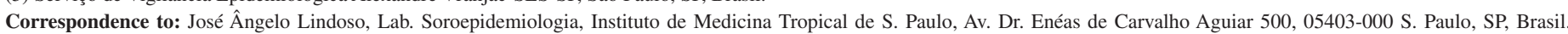
Phone: 3061-7023. E-mail: jlindoso@usp.br 
Table 1

Distribution of Neglected Tropical Diseases according to categories. (Based on panel from the TDR/World Health Organization)

\begin{tabular}{|c|c|c|}
\hline $\begin{array}{l}\text { Category } 1 . \\
\text { Emerging and } \\
\text { uncontrolled disease }\end{array}$ & $\begin{array}{l}\text { Category } 2 . \\
\text { Control strategy available } \\
\text { Disease burden persists }\end{array}$ & $\begin{array}{l}\text { Category } 3 \text {. } \\
\text { Control strategy effective } \\
\text { Disease burden falling } \\
\text { Elimination planned }\end{array}$ \\
\hline $\begin{array}{l}\text { Leishmaniasis } \\
\text { African Trypanosomiasis } \\
\text { Dengue fever }\end{array}$ & $\begin{array}{l}\text { Malaria } \\
\text { Schistosomiasis } \\
\text { Tuberculosis }\end{array}$ & $\begin{array}{l}\text { Chagas' Disease } \\
\text { Leprosy } \\
\text { Lymphatic filariasis } \\
\text { Onchocerciasis }\end{array}$ \\
\hline
\end{tabular}

Table 2.

Estimated burden of the main Neglected Tropical Diseases reported in Brazil over ten years (from 1998 through 2007)

\begin{tabular}{lccc}
\hline Neglected Tropical Diseases & Total number of reported cases & Number of deaths & Case fatality rate \\
\hline Visceral Leishmaniasis & 33,787 & 1,598 & $4.73 \%$ \\
Tegumentary Leishmaniasis (a) & 268,866 & $616^{* * *}$ & $0.22 \%$ \\
Malaria & $4,791,853$ & 960 & $0.02 \%$ \\
Dengue fever & $3,317,662$ & 463 & $0.013 \%$ \\
Tuberculosis & 631,887 & 22,937 & $3.3 \%$ \\
Chagas' Disease* & 444 & 14 & $3 \%$ \\
Schistosomiasis & $1,031,838$ & 4,539 & $0.43 \%$ \\
Leprosy**(a) & 405,860 & 11,794 & $2.9 \%$ \\
\hline
\end{tabular}

Source: Health Surveillance Service of the Ministry of Health of Brazil and DATASUS. Death by (a) were not considered basic cause of dead. * Data available only for Acute Chagas' Disease from 2005 through 2008; ** Data available from 2004 to 2006; *** Data available from 2001 to 2007.

\section{LEISHMANIASIS}

Leishmaniasis, which is caused by 20 species of the genus Leishmania sp., is pathogenic in humans and is transmitted by phlebotomine sandflies. The disease is prevalent on four continents and is considered to be endemic in 88 countries, of which 72 are developing countries. In terms of distribution, $90 \%$ of all cases of visceral leishmaniasis (VL) occur in Bangladesh, Brazil, India, Nepal, and the Sudan; $90 \%$ of all cases of the mucocutaneous form occur in Bolivia, Brazil, and Peru; and $90 \%$ of all cases of the cutaneous form occur in Afghanistan, Brazil, Iran, Peru, Saudi Arabia, and Syria ${ }^{49}$. Leishmaniasis is present in all regions of Brazil. About 28,000 and 3,000 cases of tegumentary and visceral leishmaniasis are reported per year, respectively ${ }^{6}$. In Brazil, tegumentary leishmaniasis (TL) is caused by different species of Leishmania $(L$.$) , and VL is caused only$ by $L$. chagasi. Both cutaneous and mucosal TL cause disfigurement and visceral leishmaniasis is fatal if left untreated. TL and VL are most prevalent in the north and northeast regions, respectively ${ }^{6}$. The epidemiological pattern of VL has changed. In the eighties, $90 \%$ of cases occurred in the northeast region of Brazil; in the following decade, the disease was found to be disseminated in geographic areas with a higher level of development. $\mathrm{VL}$ and TL are currently present over the entire territory and the lethality rate of $\mathrm{VL}$ is about $5 \%$. Although the disease has been known for a long time, the therapeutic arsenal for the treatment of patients with leishmaniasis is poor. In Brazil, only three drugs are available, and they present several inconveniences for patients. Firstly, the drugs can be administered only by the parenteral route and their side effects include renal damage, pancreatitis, and cardiac damage. Secondly, an increase in drug resistance has been observed. Although the Brazilian program for the control of leishmaniasis is adequate, the disease is still spreading. This spread has been related to environmental changes such as deforestation, urbanization, and migration of non-immune people to endemic areas ${ }^{9}$.

\section{MALARIA}

Malaria is caused by the Plasmodium $(P$.) species and is transmitted by bites of the female Anopheles mosquito. In Brazil, the disease is caused by $P$. vivax, $P$. malariae, and $P$. falciparum, which is responsible for the most serious form of the disease.

Data from the Health Ministry about malaria in Brazil show a clear decrease in the number of cases in the last two years as a result of integrated action by the federal, state, and municipal governments. In 2007, 457,659 cases of malaria were notified, whereas in 2005 there had been 607,827 . This represents a $150,168(24.7 \%)$ reduction in the number of sick people between 2005 and $2007^{6}$. This decrease is the result of continuous efforts carried out by the Health Department in cooperation with the state and municipal governments. According to the Health Ministry, the success in "the control of Malaria results from continuous efforts carried out through the integration of surveillance and improvement in population access to health services" ${ }^{\text {. }}$ 
Between 2006 and 2007, the state of Acre showed the most significant reduction in malaria cases, followed by Maranhão (-45.4\% and $-30.5 \%$, respectively). The states of Tocantins and Rondônia also showed a decrease (24\% and $19.5 \%$, respectively). Only the states of Amazonas and Mato Grosso showed an increase in the number of cases, with increases of $6.0 \%$ and $1.5 \%$, respectively. Brazil also showed an overall reduction in the number of deaths and hospital admissions ${ }^{6}$. In Legal Amazonia, a zone that covers $99.9 \%$ of malaria notifications in the country, there was a $54.4 \%$ reduction in the number of deaths ${ }^{8}$. Increases in the number of laboratories for the diagnosis of malaria (1,182 and 3,217 laboratory units in 1999 and 2007, respectively) and the introduction of new treatments for patients with malaria transmitted by $P$. falciparum were the main factors that contributed to this reduction ${ }^{4}$. These points decisively contributed to improving care for patients with malaria.

Better intersectorial integration and articulation are necessary to improve these results. Concerted action is expected from the Ministries of Agrarian Reform, Mines and Energy, Transport, Defense, Education, and Tourism to diminish eventual divergences, with a focus on the effective control of malaria ${ }^{3,4}$.

Since a vaccine against the disease is not yet available, adequate access to opportune diagnosis and intervention is necessary to avoid unnecessary deaths ${ }^{3,4}$.

\section{CHAGAS' DISEASE}

Chagas' disease is transmitted mainly by Triatoma insects. At the end of the seventies, a high incidence of Chagas' disease was observed in Brazil, with about 100,000 new cases per year. The chronic form of the disease can cause lesions such as cardiac failure, arrhythmia, and mega-intestine, causing poor quality of life and precocious death ${ }^{43}$.

An efficient program that includes entomologic monitoring to identify the presence of the vector, anti-vector initiatives with specific insecticidal action, and the improvement of living conditions in endemic areas will keep the disease under control. A $0.13 \%$ prevalence of Chagas' disease was observed in a multicenter study that included all endemic states in Brazil from 1989 to 1999; the study was carried out with the participation of children (aged 7-14 years) attending primary school ${ }^{43}$. With these data, ten Brazilian states (São Paulo, Rio de Janeiro, Paraíba, Mato Grosso, Mato Grosso do Sul, Goiás, Minas Gerais, Pernambuco, Tocantins, and Piauí) were certified (International Commission of Specialists of the Pan-American Health Organization, PAHO) for the interruption of vectorial transmission of Chagas' disease by T. infestans. Similar studies are being conducted in other states, and the Health Authorities are expected to obtain the same certification. T. infestans is no longer found in seven states of Brazil. In the Amazon region, changes in landscape, the migration of populations from Chagas-endemic areas, the diversity of wild T. cruzi reservoir hosts, and the variety of vector species resulted in intense sylvatic transmission. Since such condition favors the emergence and expansion of Chagas' disease, the development of specific actions is necessary to control the disease in the Amazon area ${ }^{6}$. In Brazil, transfusional transmission is controlled and other vectors are under surveillance. In the same vein, procedures such as the improvement of household and living conditions were undertaken, aiming at a proximate interruption of vectorial transmission. Currently, the main problem is related to chronic patients who present cardiac failure or mega-colon; the occurrence of acute Chagas' disease in foci and transmission by oral ingestion are additional problems. Some reports of outbreaks in different areas of Brazil show a relationship between Chagas' disease and the ingestion of aça $\hat{1}^{35}$, a typical food of Amazonas, and sugarcane juice ${ }^{45}$.

\section{DENGUE FEVER}

Dengue illness is caused by any of four different serotypes. It is currently considered the most important mosquito-borne viral disease in humans who live in the tropical and subtropical areas of the world. Dengue is one of the main public health problems in the world. The WHO indicates that 50 to 100 million people are infected annually in more than 100 countries, on all continents except Europe. About 550,000 sick people need hospitalization and 20,000 die as a consequence of the disease. Dengue is a disease with a wide clinical spectrum. The prognosis of dengue hemorrhagic fever depends on early diagnosis and treatment, which can reduce the disease's lethality ${ }^{24}$. In Brazil, social conditions such as poverty, poor sanitation and education, as well as environmental determinants such as temperature, latitude, longitude, and disorganized urbanization, favored the expansion of Aedes aegypti and facilitated its dispersion since it was re-introduced in $1976^{6}$. This vector has a high capacity of adaptation to urban conditions and could not to be controlled with traditional methods. In Brazil, dengue fever generally occurs from January to May. Since 1996, it has occurred every year throughout the country. Serotype 3 is the strain with the highest circulation; serotypes 1 and 2 also occur, although with a lower frequency. Programs based on chemical management, which typically involve little participation from the community, were unable to control vector dissemination. In 1990, the introduction and rapid dissemination of serotype 3 paved the way for large-scale epidemics and increases in the number of cases of the hemorrhagic form. Brazilian health authorities extended the control of disease progression with the National Plan for the Control of Dengue (PNCD). The PNCD fortified surveillance as a health priority, with initiatives such as educational campaigns, population mobilization to keep potential niches in the environment free of vectors, improvement in both health professionals' qualifications and vector combat, and continued evaluation of control initiatives in states and cities. The dissemination of arboviruses is related to poverty, low wages, and health care inequity ${ }^{26}$. Yellow fever, another arbovirus disease, is difficult to control and is not related only to poverty. The main problem is that arboviruses are present in tropical countries, particularly in countries where great social differences contribute to making people more vulnerable to this kind of diseases $^{26}$.

\section{TUBERCULOSIS}

Tuberculosis (TB) is an important public health problem in 22 developing countries. Eighty percent of the worldwide cases occurred in these countries. According to recent estimates, about one-third of the worldwide population is infected with Mycobacterium tuberculosis and is thus at risk of developing the disease ${ }^{10}$. Eight million new cases and almost three million deaths are registered every year. In developed countries, aged people, ethnic minorities, and immigrants are the most affected. In developing countries, the economically active population (aged 15-54 years) is also affected by $\mathrm{TB}^{4}$. Males are twice as susceptible to this disease as women. In these countries, determinant factors such as poverty, alcohol abuse, and malnutrition influence vulnerability to this infectious disease ${ }^{3}$. In Brazil, more than 50 million people are infected 
with the TB bacillus ${ }^{6}$. About 100,000 new cases are notified every year and there are about five thousand to six thousand yearly deaths due to this disease ${ }^{6}$. Acquired Immunodeficiency Syndrome (AIDS) was a determinant factor in the resurgence of $\mathrm{TB}^{50}$. In developed countries, the increase in the number of cases of multidrug-resistant TB (MDR-TB) is another concerning problem. In Brazil, intermediate-level incidence of MDR-TB has been observed ${ }^{47}$. The association of tuberculosis and AIDS has become a serious public health problem, raising the morbidity and mortality indices of $\mathrm{TB}^{10}$. Although TB is a serious disease, it is curable in most new cases. In parallel to prove treatment for TB patients, health authorities also want to eliminate the major sources of infection ${ }^{6}$. In São Paulo city (2002), 416 deaths occurred from non-AIDS-associated TB ${ }^{27}$. Male adults over 50 years of age, migrants, and people living in districts with a low-ranked HDI are more likely to die from TB. Low education level and co-morbidity are relevant characteristics. Low involvement of primary care units in TB diagnosis and frequent underreporting of cases were also analyzed in that study ${ }^{27}$. It is important to emphasize that both AIDS and TB treatments are free of charge and available in hospitals of the Public Health System, thus contributing to improvement of the control of these diseases. In Brazil, the introduction of highly active antiretroviral therapy had an important impact on the decrease in the number of cases of HIV/TB co-infection.

\section{LEPROSY}

Leprosy is another disease intrinsically related to poverty. The global prevalence of this disease is estimated to be 0.4 million people, mainly in India, sub-Saharan Africa, Latin America, and the Caribbean ${ }^{11}$. India and Brazil belong to the 20 countries in the world with the greatest economic power but they are among the countries most affected by leprosy. This contrast highlights the social and economic inequalities present in developing countries. In light of this, there will be soon a significant number of new cases of people with leprosy, with many of them presenting disabilities, if no effective action is taken ${ }^{11}$. Although there is a good program for the control of leprosy in Brazil, the number of cases is still high. In 2006, the prevalence rate for leprosy in Brazil was 2.37 cases per 10,000 inhabitants ${ }^{6}$. Although a decline in prevalence has been observed since 1990, the rate remains high. Regarding the detection rate, Brazil is hyperendemic in the north and center-west regions; the level of endemicity is very high in the northwest and high in the southeast, center, and south regions. According to the National Public Health Surveillance Program in Brazil, the states of Maranhão, Pará, and Mato Grosso present the highest number of patients with leprosy ${ }^{6}$. The state of Maranhão has the lowest DHI in Brazil, thus confirming the intrinsic relationship between leprosy and poverty. Although treatment for patients with leprosy is effective, with a cure rate of $90 \%$, its availability and effectiveness depends on the public health systems, especially in terms of quality and accessibility to medicines.

\section{SCHISTOSOMIASIS}

Schistosomiasis is intrinsically related to poverty and the absence of adequate sanitary conditions ${ }^{12}$. The impact of schistosomiasis can be observed in economic production, in cognitive impairment among pre-school children, and, consequently, in the country' development ${ }^{2}$. In Brazil, schistosomiasis is caused by Schistosoma mansoni, which is present in almost all territory. The disease is present in 19 states; it is endemic in eight states, with six and two of these states in the northwest and southwest regions of Brazil, respectively ${ }^{6}$. Foci of the disease occur in other states (Pará, Maranhão, Piauí, Ceará, Rio de Janeiro, Santa Catarina, São Paulo, Rio Grande do Sul, and Goiás) and in Brasília. However, the migration of people from a schistosomiasis-endemic area to areas free of the disease could contribute to disseminating the disease ${ }^{6}$. The disease can exhibit a wide spectrum of symptoms.

The national schistosomiasis control program, which was implemented in 1975, was based on: 1) improvement of sanitary conditions, including water supply, and the construction of bathrooms and septic tanks; 2) sanitary education efforts in order to reduce high-risk behavior; 3) active and passive case detection and large-scale chemotherapy; and 4) snail control according to epidemiological and ecological characteristics (WHO, 1983, 2000). After the control program was implemented in Brazil, a reduction in the prevalence of Schistosoma mansoni was observed in some areas'; in addition, the number of hospitalized individuals fell by $65 \%$ between 1988 and 1999, and specific mortality due to schistosomiasis fell by $54 \%$ between 1979 and $1997^{6}$. Similarly, the mean age at death associated with schistosomiasis rose by $32.2 \%$ between 1976 and 20032,6. Despite the decrease of schistosomiasis cases in Brazil, the disease may be considered an NTD. Currently, there are only two effective drugs available in Brazil for the treatment of patients with schistosomiasis ${ }^{25}$. Additionally, it is too difficult for the patients to access these drugs in some parts of the country. In some regions, it is also difficult for them to access a health service to diagnose schistosomiasis.

\section{ONCHOCERCIASIS}

Onchocerciasis is caused by the filarial nematode Onchocerca volvulus and is transmitted from person to person by blood-sucking black flies ${ }^{30,44}$. The main clinical manifestations are onchocercal skin disease and ocular lesions that lead to visual impairment and blindness. Cutaneous lesions are classified into acute and chronic papular dermatitis, lichenified dermatitis, atrophy, and depigmentation ${ }^{46}$. In 1995, the WHO estimated that a total of 17.7 million people were infected with $O$. volvulus; 270,000 were blind and another 500,000 had visual impairment. Recent reports indicate that these data were underestimated: 37 million people are now thought to be infected, with 90 million more at risk, in sub-Saharan Africa, and there are an estimated 400,000 infections in Latin America. In Africa, the disease is considered to have a high prevalence and morbidity has increased ${ }^{29}$. In the Americas, foci of the disease were found in six countries (Mexico, Guatemala, Colombia, Ecuador, Venezuela, and Brazil). There were an estimated thirteen foci of the disease on the American continent according to the $\mathrm{WHO}^{48}$. In Brazil, the disease occurs in the states of Roraima and Amazonas. In Brazilian Amazonia, the focus covers a large part of the Yanomami Indian territory in northwestern Roraima and central and northern Amazonas. There are about 17,000 Yanomami Indians and 10,000 of them are at risk of developing onchocerciasis ${ }^{6}$. However, statistical data on the number of Indians infected with $O$. volvulus are not available. Onchocerciasis, as well as other NTDs, has not received the due attention from the government regarding treatment and control. In relation to specific medicines for the treatment of patients with onchocerciasis, some efficacious drugs are currently available ${ }^{46}$.

\section{LYMPHATIC FILARIASIS}

Lymphatic filariasis is caused mainly by Wuchereria brancrofti 
and transmitted by Culex quinquefasciatus. It causes a chronic disease and is considered one of the main causes of disability due to infectious disease in the world. At the same time, filariasis causes social stigmatization and decrease in both job opportunities and quality of life ${ }^{32}$. The disease is prevalent in certain parts of the world, particularly in Africa, Caribbean, and Latin America ${ }^{16,37}$. In Brazil, the prevalence rate is not available from the Health Surveillance Service, but disease transmission in the Metropolitan Region of Recife, Pernambuco State, is a cause for concern ${ }^{33}$. Regarding treatment of patients with filariasis, some effective drugs are available but access to both diagnosis and drugs is again the main problem ${ }^{20}$. The incidence of the filarial carrier can be reduced by massive treatment. This can be observed in some regions of Brazil where such treatment was implemented ${ }^{6}$. Although filariasis is a public health problem in Brazil, it was considered by the WHO one of the seven diseases for which it is likely to achieve global eradication by 2020 .

\section{HOOKWORM INFECTION}

Hookworm infection is a serious health problem, mainly with regard to disability ${ }^{5}$. This is the second most important parasitic infection in humans after malaria ${ }^{7}$. This infection is included in a group of major poverty-promoted chronic and disabling tropical infections considered as NTDs. Necator americanus and Ancylostoma duodenale, which are nematode parasites, are considered the main causes of human hookworm infection ${ }^{7}$. They are distributed in most parts of the world, mainly in developing regions of the tropics, occurring in rural areas of extreme poverty ${ }^{20}$. About 600 million individuals with hookworm infection are distributed mainly in agricultural areas inhabited by about 2.7 billion people who live on less than $\$ 2$ per day ${ }^{20,31}$. Environment and socioeconomic status are the two most important factors determining how hookworm infection is acquired ${ }^{31}$. In the Americas, its prevalence is estimated to be about 50 million cases. The mechanism by which poverty favors hookworm infection is based on inadequate sanitation, poor housing construction, and lack of access to essential medicines ${ }^{13}$. In Brazil, the factors described above are present in some places, mainly in the rural areas of the north and northeast regions. There is a high number of people with hookworm infection in these areas, which is in agreement with the assumption that poverty strictly favors hookworm infection. Although medicines are currently available for the treatment of patients with this disease, the major obstacle is drug distribution?

\section{CO-INFECTION WITH NTDs AND HIV}

Another problem related to NTDs is co-infection with HIV ${ }^{22}$. The burden of NTDs in HIV-infected patients around the world has increased. Since 1980, visceral leishmaniasis (VL) has reemerged in Mediterranean countries, mainly among HIV-infected drug users ${ }^{1}$. Currently, an increase has been observed in the number of Leishmania-HIV co-infected patients, who have different clinical presentation or fail to respond to specific antiLeishmania treatment ${ }^{1}$. Recently, we reported a case series of patients with HIV infection and tegumentary leishmaniasis (TL) with unusual manifestation $^{28}$, and TL was described as a manifestation of immune reconstitution inflammatory syndrome in HIV-infected patients ${ }^{38}$. Data from the Epidemiological Surveillance Center in São Paulo show that the rate of failure of treatment with liposomal amphotericin B in patients with VL infection is higher in HIV-co-infected patients than in those not infected with HIV.
In patients co-infected with malaria and HIV, malaria contributes to worsening the immunosuppression caused by HIV infection. There is evidence that non-pregnant women infected with HIV are more vulnerable to malaria than those without HIV infection ${ }^{3,4}$. Chagas' disease is also affected by HIV infection. It has been observed that, in patients with the chronic form of Chagas' disease, the acute form of the disease reactivates due to the severe immunosuppression caused by HIV infection ${ }^{41,42}$. Also, leprosy can course with a more severe clinical manifestation in HIV-infected patients. Recently, we observed that HIV infection can modify the manifestation of paracoccidioidomycosis in severely immunosuppressed patients (personal communication).

Co-infection with HIV and NTDs can course with more severe manifestations or lead to failure to respond to specific treatments. In fact, co-infection with HIV and NTDs is a new type of co-morbidity that requires additional knowledge and greater integration between HIV and NTD research than currently observed.

\section{CONCLUDING REMARKS}

NTDs occur in areas where poverty is endemic ${ }^{23}$. It is generally accepted that NTDs and low-level HDI are related ${ }^{31}$. This association can be confirmed by observing the prevalence of the main NTDs in the world. These diseases are prevalent in tropical and subtropical areas (Fig. 1 ), in countries with a high index of poverty, and where most inhabitants live on less than two dollars a day. In Brazil, NTDs are most prevalent in the north and northeast regions, which present the lowest HDIs in the country (Fig. 2). According to the WHO, the main NTDs can be classified into three groups. Leishmaniasis, human African trypanosomiasis (HAT), and dengue fever are considered the most important NTDs. All other NTDs except for HAT occur in various regions of Brazil. TL, VL, and dengue fever occur all over the territory and malaria occurs mainly in northern Brazil. Other NTDs occur in outbreaks, like onchocerciasis, which is limited to the Yanomami Indian area (north region), and lymphatic filariasis, which occurs only in the Metropolitan region of Recife (Pernambuco State). The situation is different in the USA, where soil-transmitted helminth infections, which are most prevalent among immigrants, refugees, and Black women, are the main neglected infectious diseases; these infections are also typical of poverty ${ }^{15}$. In Brazil, the populations most affected by NTDs live in rural areas and in suburbs of large cities, where there is the highest prevalence of poverty ${ }^{31}$. Co-factors such as deforestation, sparse health service coverage, and lack of control of natural resources, may even worsen poverty ${ }^{20}$. Co-infection with HIV is a new problem related to NTDs ${ }^{22}$. In cases of co-infection, NTDs show different clinical manifestations or the patients fail to respond to specific treatments. In terms of drug availability and drugs developed exclusively for NTDs, the investments are clearly insufficient ${ }^{39}$. Although 1,556 new drugs were developed in the world from 1975 to 2004, only 21 of them are indicated for patients with $\mathrm{NTDs}^{40}$. Vaccines might be used either as lone control tools or combined with specific drugs in programs of vaccine-linked chemotherapy to prevent these diseases. However, an effective vaccine is not yet available ${ }^{17,36}$. Certain obstacles make it difficult to develop NTD vaccines. One of these obstacles is that many NTDs are zoonoses that occur in large mammalian reservoirs, and the development of veterinary vaccines would be necessary to interrupt transmission. The eradication or reduction of NTDs would have a direct effect on socioeconomic development and poverty ${ }^{17,19}$. Because such vaccines are specific to NTDs, they are sometimes referred to as 'antipoverty' 


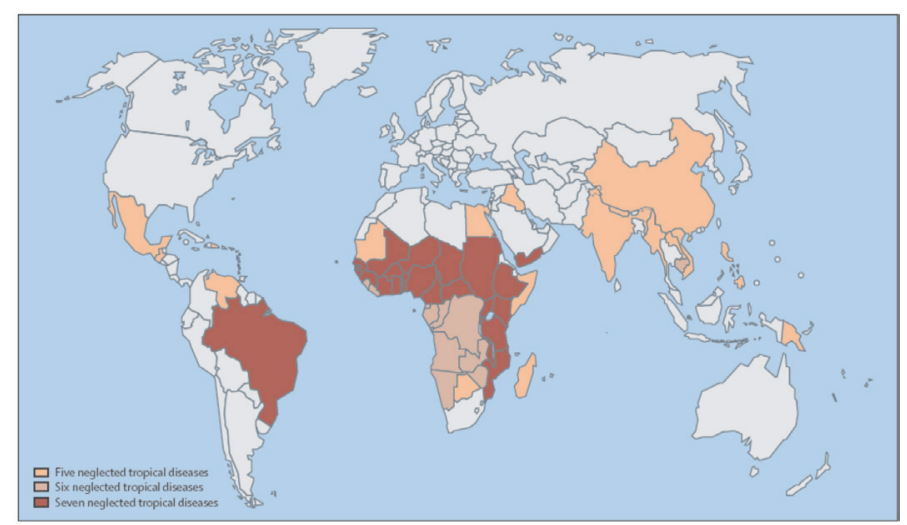

Fig. 1 - Map showing the geographic overlap and distribution of the seven most common neglected tropical diseases in the World. Reproduced with permission from Elsevier (License number 2218920197726).
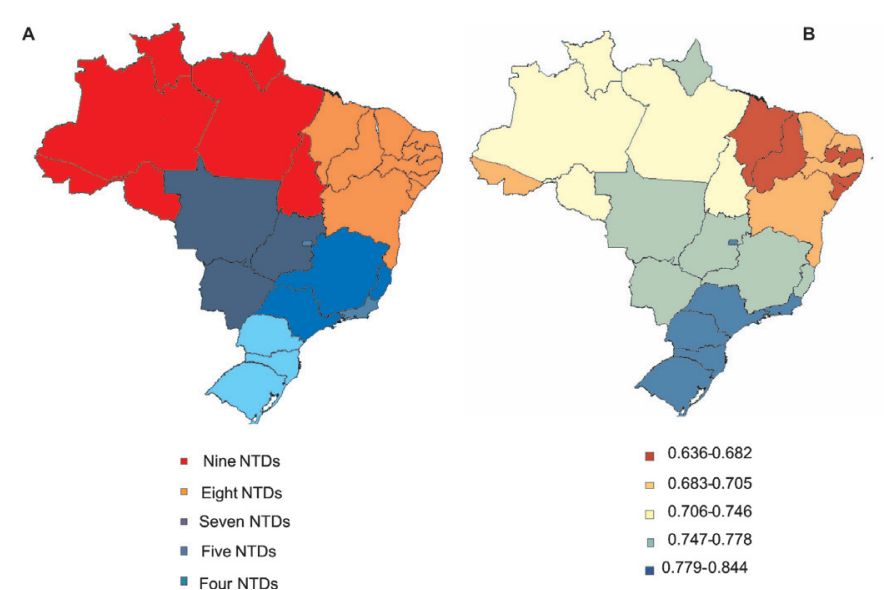

Fig. 2 - Map of Brazil showing the geographic overlap and distribution of the main neglected tropical diseases (A) according to the health surveillance service (Ministry of Health) and the distribution of human development index (B) according to the Brazilian Institute of Geography and Statistics (IBGE).

vaccines ${ }^{19}$. Although investment in NTDs has increased, stronger efforts by governmental and private organisms are required to decrease the morbidity and mortality caused by these diseases ${ }^{18,34}$.

\section{RESUMO}

\section{Doenças tropicais negligenciadas no Brasil}

A pobreza está intrinsicamente relacionada com a ocorrência de doenças tropicais negligenciadas (DTNs). Os principais países com os menores índices de desenvolvimento humano (IDH) e a maior carga de DTNs estão nas regiões tropicais e subtropicais do globo terrestre. O Brasil é o $70^{\circ}$ país no ranking do IDH e concentra nove das 10 principais doenças tropicais consideradas negligenciadas pela OMS. Leishmanioses, tuberculose, dengue e hanseníase ocorrem em quase todo o território do Brasil. Mais de $90 \%$ dos casos de malária ocorrem na região norte e há surtos de filariose linfática e oncocercose. As regiões norte e nordeste apresentam o menor IDH e concentram o maior número das DTNs. Essas doenças são consideradas negligenciadas devido à falta de investimento no desenvolvimento de novas drogas e vacinas e também pela pouca eficácia dos programas de controle. Um problema preocupante em relação às DTNs é a co-infecção com HIV, que favorece manifestações clínicas graves e falência terapêutica. Neste artigo, a situação das principais DTNs no Brasil é descrita e correlacionada com o IDH e a pobreza.

\section{ACKNOWLEDGMENTS}

The authors acknowledge Dr Paulo Boschcov, former professor at UNIFESP, whose suggestions contributed to improve the quality of the final version of the manuscript.

\section{REFERENCES}

1. ALVAR, J.; APARICIO, P.; ASEFFA, A. et al. - The relationship between leishmaniasis and AIDS: the second 10 years. Clin. Microbiol. Rev., 21: 334-359, 2008.

2. AMARAL, R.S.; TAUIL, P.L.; LIMA, D.D. \& ENGELS, D. - An analysis of the impact of the Schistosomiasis Control Programme in Brazil. Mem. Inst. Oswaldo Cruz, 101 (suppl. 1): 79-85, 2006

3. BATES, I.; FENTON, C.; GRUBER, J. et al. - Vulnerability to malaria, tuberculosis, and HIV/AIDS infection and disease. Part II: Determinants operating at environmental and institutional level. Lancet infect. Dis., 4: 368-375, 2004.

4. BATES, I.; FENTON, C.; GRUBER, J. et al. - Vulnerability to malaria, tuberculosis, and HIV/AIDS infection and disease. Part 1: Determinants operating at individual and household level. Lancet infect. Dis., 4: 267-277, 2004.

5. BETHONY, J.; BROOKER, S.; ALBONICO, M. et al. - Soil-transmitted helminth infections: ascariasis, trichuriasis, and hookworm. Lancet, 367: 1521-1532, 2006.

6. BRASIL. MINISTÉRIO DA SAÚDE. SECRETARIA DE VIGILÂNCIA EM SAÚDE Vigilância em Saúde. 2009. Available at: www.saude.gov.br/svs (accessed July 2009).

7. BROOKER, S.; BETHONY, J. \& HOTEZ, P.J. - Human hookworm infection in the $21^{\text {st }}$ century. Advanc. Parasit., 58: 197-288, 2004.

8. DA SILVA-NUNES, M.; CODECO, C.T.; MALAFRONTE, R.S. et al. - Malaria on the Amazonian frontier: transmission dynamics, risk factors, spatial distribution, and prospects for control. Amer. J. trop. Med. Hyg., 79: 624-635, 2008.

9. DESJEUX, P. - The increase in risk factors for leishmaniasis worldwide. Trans. roy. Soc. trop. Med. Hyg., 95: 239-243, 2001.

10. DYE, C.; BASSILI, A.; BIERRENBACH, A.L. et al. - Measuring tuberculosis burden, trends, and the impact of control programmes. Lancet infect. Dis., 8: 233-243, 2008.

11. GOULART, I.M. \& GOULART, L.R. - Leprosy: diagnostic and control challenges for a worldwide disease. Arch. Derm. Res., 300: 269-290, 2008.

12. HOPKINS, D.R.; RICHARDS Jr., F.O.; RUIZ-TIBEN, E.; EMERSON, P. \& WITHERS Jr., P.C. - Dracunculiasis, onchocerciasis, schistosomiasis, and trachoma. Ann. N. Y. Acad. Sci., 1136: 45-52, 2008.

13. HOTEZ, P. - Hookworm and poverty. Ann. N.Y. Acad. Sci., 1136: 38-44, 2008.

14. HOTEZ, P.J. - The giant anteater in the room: Brazil's neglected tropical diseases problem. PLoS Negl. trop. Dis., 2: e177, 2008.

15. HOTEZ, P.J. - Neglected infections of poverty in the United States of America. PLoS Negl. trop. Dis., 2: e256, 2008.

16. HOTEZ, P.J.; BOTTAZZI, M.E.; FRANCO-PAREDES, C.; AULT, S.K. \& PERIAGO, M.R. - The neglected tropical diseases of Latin America and the Caribbean: a review of disease burden and distribution and a roadmap for control and elimination. PLoS Negl. trop. Dis., 2: e300, 2008. 
17. HOTEZ, P.J. \& BROWN, A.S. - Neglected tropical disease vaccines. Biologicals, 37: 160-164, 2009

18. HOTEZ, P.J; FENWICK, A.; SAVIOLI, L. \& MOLYNEUX, D.H. - Rescuing the bottom billion through control of neglected tropical diseases. Lancet, 373: 1570-1575, 2009.

19. HOTEZ, P.J. \& FERRIS, M.T. - The antipoverty vaccines. Vaccine, 24: 5787-5799, 2006

20. HOTEZ, P.J.; MOLYNEUX, D.H.; FENWICK, A. et al. - Control of neglected tropical diseases. New Engl. J. Med., 357: 1018-1027, 2007.

21. HOTEZ, P.J.; MOLYNEUX, D.H.; FENWICK, A. et al. - Incorporating a rapid-impact package for neglected tropical diseases with programs for HIV/AIDS, tuberculosis, and malaria. PLoS Med., 3: e102, 2006.

22. HOteZ, P.J.; MOLYNEUX, D.H.; STILlWAGGON, E.; BENTWICH, Z. \& KUMARESAN, J. - Neglected tropical diseases and HIV/AIDS. Lancet, 368:18651866, 2006.

23. HOTEZ, P.J.; REMME, J.H.; BUSS, P. et al. - Combating tropical infectious diseases: report of the Disease Control Priorities in Developing Countries Project. Clin. infect. Dis., 38: 871-878, 2004.

24. KALAYANAROOJ, S. \& NIMMANNITYA, S. - Guidelines for dengue hemorrhagic fever case management. Bangkok, Bangkok Medical Publisher, 2004.

25. KATZ, N. \& COELHO, P.M. - Clinical therapy of schistosomiasis mansoni: the Brazilian contribution. Acta trop., 108: 72-78, 2008

26. LABEAUD, A.D. - Why arboviruses can be neglected tropical diseases. PLoS Negl. trop. Dis., 2: e247, 2008.

27. LINDOSO, A.A; WALDMAN, E.A.; KOMATSU, N.K. et al. - Profile of tuberculosis patients progressing to death, city of Sao Paulo, Brazil, 2002. Rev. Saude públ. (S. Paulo), 42: 805-812, 2008.

28. LINDOSO, J.A.; BARBOSA, R.N.; POSADA-VERGARA, M.P. et al. - Unusual manifestations of tegumentary leishmaniasis in AIDS patients from the New World. Brit. J. Derm., 160: 311-318, 2009.

29. LITTLE, M.P.; BASANEZ, M.G.; BREITLING, L.P.; BOATIN, B.A. \& ALLEY, E.S. - Incidence of blindness during the onchocerciasis control programme in western Africa, 1971-2002. J. infect. Dis., 189: 1932-1941, 2004.

30. MARCHON-SILVA, V.; CAER, J.C.; POST, R.J.; MAIA-HERZOG, M. \& FERNANDES, O. - Detection of Onchocerca volvulus (Nematoda: Onchocercidae) infection in vectors from Amazonian Brazil following mass Mectizan distribution. Mem. Inst. Oswaldo Cruz, 102: 197-202, 2007.

31. MATHERS, C.D., EZZATI, M. \& LOPEZ, A.D. - Measuring the burden of neglected tropical diseases: the global burden of disease framework. PLoS Negl. trop. Dis., 1: e114, 2007

32. MATTOS, D. \& DREYER, G. - A complexidade do custo sócio-econômico da filariose linfática. Rev. Soc. bras. Med. trop., 41: 399-403, 2008.

33. MEDEIROS, Z.; BONFIM, C.; ALVES, A. et al. - The epidemiological delimitation of lymphatic filariasis in an endemic area of Brazil, 41 years after the first recorded case. Ann. trop. Med. Parasit., 102: 509-519, 2008.

34. MOREL, C.M.; ACHARYA, T.; BROUN, D. et al. - Health innovation networks to help developing countries address neglected diseases. Science, 309: 401-404, 2005.
35. NOBREGA, A.A.; GARCIA, M.H.; TATTO, E. et al. - Oral transmission of Chagas disease by consumption of acai palm fruit, Brazil. Emerg. infect. Dis., 15: 653-655, 2009.

36. PANG, T. - Vaccines for the prevention of neglected diseases -- dengue fever. Curr. Opin. Biotechnol., 14: 332-336, 2003.

37. PERERA, M.; WHITEHEAD, M.; MOLYNEUX, D.; WEERASOORIYA, M. \& GUNATILLEKE, G. - Neglected patients with a neglected disease? A qualitative study of lymphatic filariasis. PLoS Negl. trop. Dis., 1: e128, 2007.

38. POSADA-VERGARA, M.P.; LINDOSO, J.A.; TOLEZANO, J.E. et al. - Tegumentary leishmaniasis as a manifestation of immune reconstitution inflammatory syndrome in 2 patients with AIDS. J. infect. Dis., 192: 1819-1822, 2005.

39. REDDY, M.; GILL, S.S.; KALKAR, S.R. et al. - Oral drug therapy for multiple neglected tropical diseases: a systematic review. J. Amer. med. Ass., 298: 1911-1924, 2007.

40. RENSLO, A.R. \& McKERROW, J.H. - Drug discovery and development for neglected parasitic diseases. Nature Chem. Biol., 2: 701-710, 2006.

41. SARTORI, A.M.; IBRAHIM, K.Y.; NUNES WESTPHALEN, E.V. et al. - Manifestations of Chagas disease (American trypanosomiasis) in patients with HIV/AIDS. Ann. trop. Med. Parasit., 101: 31-50, 2007.

42. SARTORI, A.M.; LOPES, M.H.; BENVENUTI, L.A. et al. - Reactivation of Chagas' disease in a human immunodeficiency virus-infected patient leading to severe heart disease with a late positive direct microscopic examination of the blood. Amer. J. trop. Med. Hyg., 59: 784-786, 1998.

43. SECRETARIA DE VIGILÂNCIA EM SAÚDE DO MINISTÉRIO DA SAÚDE Consenso Brasileiro de Doença de Chagas. Rev. Soc. bras. Med. trop., 38 (supl. 3): 1-29, 2005.

44. SHELlEY, A.J. - Human onchocerciasis in Brazil: an overview. Cad. Saude públ. (Rio de J.), 18: 1167-1177, 2002.

45. STEINDEL, M.; KRAMER PACHECO, L.; SCHOLL, D. et al. - Characterization of Trypanosoma cruzi isolated from humans, vectors, and animal reservoirs following an outbreak of acute human Chagas disease in Santa Catarina State, Brazil. Diagn. Microbiol. infect. Dis., 60: 25-32, 2008.

46. STINGL, P. - Onchocerciasis: developments in diagnosis, treatment and control. Int. J. Derm., 48: 393-396, 2009.

47. TELLES, M.A.; FERRAZOLI, L.; WALDMAN, E.A. et al. - A population-based study of drug resistance and transmission of tuberculosis in an urban community. Int. J. Tuberc. Lung Dis., 9: 970-976, 2005.

48. VIVAS-MARTINEZ, S.; BASANEZ, M.G.; BOTTO, C. et al. - Amazonian onchocerciasis: parasitological profiles by host-age, sex, and endemicity in southern Venezuela. Parasitology, 121: 513-525, 2000.

49. WHO - Leishmaniasis. Burden of disease. 2009. Available at: http://www.who.int/ leishmaniasis/burden.en/

50. YOUNG, L.S. \& WORMSER, G.P. - The resurgence of tuberculosis. Scand. J. infect. Dis., 93(suppl): 9-19, 1994.

Received: 7 July 2009

Accepted: 2 September 2009 